\title{
WHO HAVE A HIGHER RISK OF FALLING INTO CATASTROPHIC HEALTH EXPENDITURES?
}

\author{
Amalia Noviani \\ Statistictics Indonesia, Dr. Sutomo Street 6-8 Jakarta 10710, Indonesia
}

\begin{abstract}
Catastrophic health expenditure is one of the challenges Indonesia faces in achieving Universal Health Coverage. Aside from being a financial disaster, the incident caused by out-of-pocket health expenditure exceeding a fixed limit can drive people into poverty. Unfortunately, the availability of the data causes the limitation of the study in Indonesia. This study aims to analyze the association between catastrophic health expenditure and several social-economic factors by using the latest data of out-of-pocket expenditure collected at the individual level from the 2019 Susenas Module of Health and Housing. Using the Chi-square test, this study confirms a significant association between catastrophic health expenditures and the following social-economic factors: outpatient and inpatient service use, health insurance ownership, age, sex, marital status, educational level, work status, welfare status, type of area, and geographic location. From the logistic regression, the probability of the population to experience catastrophic health expenditure is higher for people in the following categories: use inpatient or outpatient services, do not have health insurance, are elderly, ever-married, not working, not poor, and live in the rural areas or Java island. Disaggregation by outpatient and inpatient service use shows the large gap in the probability of falling into catastrophic health expenditures. The probability for people who used inpatient service is more than four times people who never used the service. Meanwhile, for outpatient service, the probability is almost three times. Therefore, people can strengthen preventive care, especially those with low or no cost, to avoid falling into catastrophic health expenditure.
\end{abstract}

Keywords: health expenditure, out-of-pocket expenditure, universal health insurance

\begin{abstract}
ABSTRAK
Pengeluaran kesehatan katastropik merupakan salah satu tantangan yang dihadapi Indonesia dalam mewujudkan Cakupan Kesehatan Semesta. Selain dapat menyebabkan bencana keuangan, insiden yang disebabkan pengeluaran kesehatan out-of-pocket melebihi batas tertentu ini dapat mendorong penduduk jatuh ke jurang kemiskinan. Hal yang patut disesali, ketersediaan data menyebabkan terbatasnya penelitian sejenis di Indonesia. Penelitian ini bertujuan untuk menganalisis hubungan antara pengeluaran kesehatan katastropik dengan beberapa faktor sosial ekonomi menggunakan data terbaru pengeluaran kesehatan out-of-pocket yang dikumpulkan pada tingkat individu melalui Susenas Modul Kesehatan dan Perumahan 2019. Dengan menggunakan Uji Chi-square, penelitian ini mengkonfimasi adanya hubungan yang signifikan antara pengeluaran kesehatan katastropik dan faktor sosial-ekonomi berikut: rawat jalan, rawat inap, kepemilikan jaminan kesehatan, umur, jenis kelamin, status perkawinan, tingkat pendidikan, status kerja, status kesejahteraan, tipe daerah, dan lokasi geografi. Dari regresi logistik diketahui bahwa peluang penduduk untuk mengalami pengeluaran kesehatan katastropik lebih tinggi pada kelompok berikut: pernah rawat inap atau rawat jalan, tidak memiliki jaminan kesehatan, berusia lanjut, pernah kawin, tidak bekerja, tidak miskin, dan tinggal di daerah perdesaan atau di Pulau Jawa. Disagregasi menurut rawat jalan dan rawat inap memperlihatkan perbedaan yang besar terkait peluang untuk mengalami pengeluaran kesehatan katastropik. Peluang untuk penduduk yang pernah rawat inap lebih dari empat kali penduduk yang tidak pernah rawat inap. Adapun untuk rawat jalan, peluangnya hampir tiga kali lipat. Oleh karena itu, penduduk dapat melakukan pemeliharaan kesehatan, utamanya yang berbiaya rendah atau tidak berbiaya sama sekali agar dapat terhindar dari pengeluaran kesehatan katastropik.
\end{abstract}

Keywords: pengeluaran kesehatan, pengeluaran out-of-pocket jaminan kesehatan universal 


\section{Introduction}

In 2019 , health insurance ownership in Indonesia had reached $66 \% .^{1}$ Even though they already have health insurance, people often need to spend money to obtain health services. People finance direct health care payments or out-of-pocket health expenditures from their household's income, savings, or loans and include no third-party payer reimbursement. ${ }^{2}$ If the expenditures exceed a fixed threshold, it could cause households to experience financial difficulties and even fall into poverty. ${ }^{3}$ It is known as catastrophic health expenditures. As one country that strives to achieve universal health coverage, the government needs to pay special attention to catastrophic health expenditures. It is undoubtedly contrary to financial protection in obtaining health services and can lead to the country's failure to achieve universal health coverage.

At the global level, many researchers carried out studies on catastrophic health expenditure. They used several thresholds to define the catastrophic health expenditure. Some researchers used the cut-off point of $10 \%{ }^{4-6}$ and $25 \%{ }^{4}$ as in Sustainable Development Goals (SDGs) Indicator 3.8.2, ${ }^{2}$ and others used $40 \%{ }^{6-9}$ In this study, we use the lowest threshold of $10 \%$ to define the incidence of catastrophic health expenditure. Several studies on catastrophic health expenditure at the global level tried to estimate the incidence, ${ }^{4,5,9,10}$ linking the incidence to various macroeconomic indicators, ${ }^{4}$ and others aimed to find the determinants. ${ }^{6-8,10}$

Meanwhile, studies on this topic in Indonesia are still limited. The researchers conducted a study in 2017 to find determinants of household catastrophic health expenditure by using the 2014 Indonesia Family Life Survey (IFLS). ${ }^{11}$ In the same year, a study was also conducted using four waves of the IFLS years 1993, 1997, 2000, and 2007 to estimate the incidence of catastrophic health expenditure. ${ }^{12}$ Later, in 2018 , the researchers also conducted a study using data from the 2012 National Socio-Economic Survey (Susenas) to determine the effect of health insurance ownership on household catastrophic health expenditure. ${ }^{3}$

The limited studies on catastrophic health expenditure in Indonesia and the availability of the out-of-pocket health expenditure data are inseparable. Thus, since 2018 Statistics Indonesia (BPS) collects out-of-pocket health expenditures at the household level twice a year using the Susenas. Through the 2019 Susenas Module of Health and Housing, BPS explicitly prepared the questionnaire to collect out-of-pocket health expenditures data at the individual level. This availability of data makes it possible to analyze at the individual level.

This study aims to analyze the association between catastrophic health expenditure in Indonesia and several social-economic factors. Therefore, we can get insight into who has a higher risk of falling into catastrophic health expenditures. Previous studies confirmed outpatient service use $^{10}$ inpatient service use, ${ }^{8,10}$ health insurance ownership, ${ }^{6,10}$ age, ${ }^{10}$ sex,${ }^{3}$ marital status, ${ }^{3}$ 
educational level, ${ }^{6,9,10}$ work status, ${ }^{10}$ welfare status, ${ }^{8,10}$ type of area, ${ }^{10}$ and geographic location, ${ }^{6,9}$ determine catastrophic health expenditure. We hope that this study can provide an overview of catastrophic health expenditures in Indonesia. Thus, the government can utilize it in formulating policies to achieve universal health coverage in this country.

\section{Method}

This study uses secondary data, namely the 2019 Susenas Module of Health and Housing. Therefore, the concepts used in this study refer to those used in the survey. BPS carries out the survey once every three years. Sample as many as 75,000 households spread across 34 provinces in Indonesia. ${ }^{13}$ Since there were household samples that no-response, the number of samples used in this study is 74,284 households or 278,004 people.

The 2019 Susenas Module of Health and Housing collected out-of-pocket health expenditure data at the individual level. In this study, we generate out-of-pocket health expenditures by adding up out-of-pocket spending for the following components in a month: (1) medicine costs for practicing self-medication, (2) outpatient costs in the government hospital, private hospital, doctor/midwife service, clinic/doctor's joint service, public health center/subsidiary of the public health center, (3) inpatient costs in the government hospital, private hospital, midwife service, clinic/doctor's joint service, public health center, (4) cost of medical equipment, health test, and health maintenance.

We obtain the population's catastrophic health expenditure status by comparing out-ofpocket health expenditures at the household level in a month with the total monthly household expenditures multiplied by $100 \%$. If the proportion is more than $10 \%$, the population is experiencing catastrophic health expenditures. We use this cut-off point based on one of the thresholds used to estimate Indicator 3.8.2 in SDGs. The previous study in Indonesia also used this cut-off point to define the catastrophic health expenditure. ${ }^{3}$

Each independent variable in this study consists of two categories. Therefore, we group the categories in the microdata for health insurance ownership, age, marital status, educational level, and geographic location. In outpatient service use, we define people who used outpatient service if they have health problems and used outpatient service in the last month. Meanwhile, for inpatient service use, people have used inpatient service if they have been used inpatient service in the last year. We define the work status by considering the work activities carried out last week or temporarily not working. Lastly, the welfare status is obtained by sorting all sample households' average monthly per capita expenditure and dividing them into two categories (40\% lowest and $60 \%$ highest).

In this study, we conduct a Chi-square test to see the association between variables. The Chisquare test of independence can determine the independence between two categorical variables in a 
single sample. ${ }^{14}$ We use the weight that is available in the microdata. We also conduct an inferential analysis using logistic regression and a goodness-of-fit test for the model. ${ }^{15} \mathrm{We}$ use the p-value for each category and odds ratios from logistic regression to answer who is experiencing catastrophic health expenditure. For all the analyses, we use an alpha of 0.05 .

\section{Results}

In terms of the number of samples, variables of inpatient service use show the largest gap. The percentage of samples who use inpatient service is below 5\%. Therefore, the percentage of people who do not use inpatient services use is above $95 \%$. The number of samples by age also shows a ratio that is similar to inpatient service use. The percentage of elderly in samples is $5,8 \%$ meanwhile the other category is $94,2 \%$. The number of samples in outpatient service use, health insurance ownerships, and geographic location also show the large gap between categories. The ratio between categories in those three variables is about 7:3. The number of samples is bigger for people who do not use outpatient services, own health insurance and live outside Java Island. It can be seen in Table 1.

The variables of marital status, educational level, work status, welfare status, and type of area show a ratio that does not have much difference between categories. However, the number of samples is higher in the following categories: ever married, highest level education completed is a primary school or lower, not working, and not poor, and live in the rural area. Meanwhile, for the variable of sex, the percentage of males and females is balanced.

Table 1. The Characteristics of Samples

\begin{tabular}{llrr}
\hline & Variable & Total & Percent \\
\hline Outpatient service use & Do not use outpatient service & 239,897 & 86.3 \\
& Use outpatient service & 38,107 & 13.7 \\
Inpatient service use & Do not use inpatient service & 264,746 & 95.2 \\
& Use inpatient service & 13,258 & 4.8 \\
Health insurance ownership & Do not own health insurance & 82,121 & 29.5 \\
& Own health insurance & 195,883 & 70.5 \\
Age & Not elderly & 261,852 & 94.2 \\
& Elderly & 16,152 & 5.8 \\
Sex & Male & 139,526 & 50.2 \\
Marital status & Female & 138,478 & 49.8 \\
\multirow{2}{*}{ Educational level } & Single & 124,904 & 44.9 \\
\multirow{3}{*}{ Work status } & Ever married & 153,100 & 55.1 \\
\multirow{2}{*}{ Welfare status } & Sprimary school & 167,086 & 60.1 \\
\multirow{2}{*}{ Type of area } & primary school & 110,918 & 39.9 \\
& Not working & 145,252 & 52.2 \\
Geographic location & Working & 132,752 & 47.8 \\
& Not poor & 166,802 & 60.0 \\
& Poor & 111,202 & 40.0 \\
\hline
\end{tabular}


The Chi-square test shows outpatient and inpatient service use, health insurance ownership, age, sex, marital status, educational level, work status, welfare status, type of area, and geographic location have p-value less than the alpha of 0.05 . It can be seen in Table 2. It means all of the variables are significantly associated with catastrophic health expenditure. Therefore, all of the variables will be used in the logistic regression. The goodness-of-fit test for the logistic regression model using survey data shows a p-value of 0.7 . Since the $p$-value is more than the alpha of 0.05 , it indicates that the model adequately describes the data.

Table 2. The Chi-Square Test of Independent

\begin{tabular}{lcc}
\hline \multicolumn{1}{c}{ Variable } & Chi-Square Value & P-Value \\
\hline Outpatient service use & $2,140,188.7$ & $0.000^{*}$ \\
Inpatient service use & $3,325,341.4$ & $0.000^{*}$ \\
Health insurance ownership & $202,821.7$ & $0.000^{*}$ \\
Age & $331,347.0$ & $0.000^{*}$ \\
Sex & $5,319.7$ & $0.000^{*}$ \\
Marital status & $121,417.3$ & $0.000^{*}$ \\
Educational level & $16,456.9$ & $0.000^{*}$ \\
Work status & $26,991.6$ & $0.000^{*}$ \\
Welfare status & $179,656.3$ & $0.000^{*}$ \\
Type of Area & 9.0 & $0.003^{*}$ \\
Geographic location & $429,634.8$ & $0.000^{*}$ \\
\hline Note* *Significant at $\alpha=0.05$ & &
\end{tabular}

Note: *Significant at $\alpha=0.05$

Table 3. The Results of Logistic Regression

\begin{tabular}{|c|c|c|c|c|}
\hline \multicolumn{2}{|c|}{ Variable } & \multirow[t]{2}{*}{$\mathbf{t}$} & \multirow[t]{2}{*}{ P-Value } & \multirow[t]{2}{*}{ Odds Ratio } \\
\hline Outpatient service use & Do not use outpatient service & & & \\
\hline & Use outpatient service & 24,0 & $0.000^{*}$ & 2.5 \\
\hline \multirow[t]{2}{*}{ Inpatient service use } & Do not use inpatient service & & & \\
\hline & Use inpatient service & 30,1 & $0.000 *$ & 4.1 \\
\hline \multirow[t]{2}{*}{ Health insurance ownership } & Do not own health insurance & & & \\
\hline & Own health insurance & $-13,8$ & $0.000^{*}$ & 0.6 \\
\hline \multirow[t]{2}{*}{ Age } & Not elderly & & & \\
\hline & Elderly & 5,9 & $0.000^{*}$ & 1.4 \\
\hline \multirow[t]{2}{*}{ Sex } & Male & & & \\
\hline & Female & $-1,9$ & 0.061 & 0.9 \\
\hline \multirow[t]{2}{*}{ Marital status } & Single & & & \\
\hline & Ever married & 3.5 & $0.000 *$ & 1.2 \\
\hline \multirow[t]{2}{*}{ Educational level } & $\leq$ primary school & & & \\
\hline & $>$ primary school & 0.5 & 0.645 & 1.0 \\
\hline \multirow[t]{2}{*}{ Work status } & Not working & & & \\
\hline & Working & -2.2 & $0.026^{*}$ & 0.9 \\
\hline \multirow[t]{2}{*}{ Welfare status } & Not poor & & & \\
\hline & Poor & $-9,3$ & $0.000^{*}$ & 0.7 \\
\hline \multirow{2}{*}{ Type of area } & Rural & & & \\
\hline & Urban & $-4,1$ & $0.000^{*}$ & 0.9 \\
\hline \multirow{2}{*}{ Geographic location } & Outside Java Island & & & \\
\hline & Java Island & 16,0 & $0.000^{*}$ & 1.7 \\
\hline Constant & & -79.9 & $0.000 *$ & 0.0 \\
\hline
\end{tabular}

Note: *Significant at $\alpha=0.05$

Outpatient and inpatient service use significantly affect the probability of falling into catastrophic health expenditures. The probability of the population experiencing catastrophic health 
expenditure for people who used inpatient service in the past year was more than four times people who never used the service. Meanwhile, the probability of the population experiencing catastrophic health expenditure for people who had health problems and used outpatient service in the last month was almost three times people who never used the service. As in health insurance ownership, the probability of the population experiencing catastrophic health expenditure is lower for those with health insurance. It can be seen in Table 3 .

In terms of age, the elderly, or the population in unproductive age of 65 years old and over has probability 1.4 times higher to fall into catastrophic health expenditure than the population age 0-64 years old. The probability of the population experiencing catastrophic health expenditure for ever-married people is 1.2 times higher than the single ones. Meanwhile, the probability of falling into catastrophic health expenditures between males and females is not different.

Similar to sex, the probability of falling into catastrophic health expenditure for educational level is the same between each category on those variables. As in work status, the probability of the population experiencing catastrophic health expenditure is lower for working. Based on welfare status, the probability of the population experiencing catastrophic health expenditure is higher in the population who belongs to the highest $60 \%$ group or are not poor.

The probability of falling into catastrophic health expenditure is higher for the population living in rural areas than those living in urban areas. Meanwhile, for the last variable, i.e., geographic location, the population living in Java Island has probability 1.7 times higher to fall into catastrophic health expenditure than those living outside Java Island.

\section{Discussion}

Our results indicate an association between outpatient and inpatient service use with catastrophic health expenditure. ${ }^{8,10}$ Our results also confirm that people who use outpatient or inpatient services have more risk of experiencing catastrophic health expenditures. It is because they are more likely to spend out-of-pocket health expenditures. Thus, when these expenditures and income increase do not balance, people can fall into catastrophic health expenditures.

To avoid using outpatient or inpatient services, people can maintain their health with lowcost to no-cost activities. They can try to eat nutritious food or do light exercise activities at home regularly. On the other hand, the government can promote healthy living, for example, by strengthening the movement of Clean and Healthy Lifestyle or Perilaku Hidup Bersih dan Sehat (PHBS) and the Peoples Healthy Lifestyle Movement or Gerakan Masyarakat Hidup Sehat (GERMAS).

Health insurance can act as a safety net for financial needs in obtaining health services. The ownership of health insurance can reduce out-of-pocket health expenditure. ${ }^{16}$ Therefore, this can also decrease the risk of experiencing catastrophic health expenditures. ${ }^{6} 10$ In reality, having health 
insurance does not always make our out-of-pocket health expenditures equal zero in outpatient and inpatient services. People who use inpatient rooms or drugs at a higher rate than their health insurance coverage will need to pay the remaining costs. Some people even choose not to use their health insurance to obtain healthcare in healthcare facilities.

In 2020, 3.6\% of people who have National Health Insurance (BPJS Kesehatan)/Regional Health Insurance (Jamkesda) never utilized their health insurance for medical examination, including outpatient service in the last year due to long waiting time. While the other $0.7 \%$ consider the procedures/requirements are hard to fulfill. As for inpatient service, the percentage is $0.4 \%$ and $0.2 \%{ }^{1}$ On the contrary, there are also cases when the condition forces people to spend out-ofpocket health expenditure when using inpatient or outpatient services. For example, spending for drugs uncovered by health insurance or the healthcare facilities does not accept their health insurance.

Age groups are significantly associated with catastrophic health expenditures. The previous study in Bangladesh found the positive influence of out-of-pocket health expenditures and old age. ${ }^{17}$ Meanwhile, the study in Nepal stated that households tend to face catastrophic health expenditures if the households consist of one/more elderly members. ${ }^{18}$ A systematic review conducted in 2019 also confirms this finding. It stated that the presence of an elderly member was one of the common factors that significantly associated with catastrophic health expenditures. ${ }^{19}$

In $2019,51.1 \%$ of people aged 60 years or more in Indonesia had health problems last month. Meanwhile, the percentage in 2020 is $48.1 \%$. The percentage of elderly that have a health problem is the highest than another age group. ${ }^{1}$ People who have health problems will increase their chances of seeking treatment. Therefore, it will also increase the possibility of spending outof-pocket health expenditures. This finding supports our results that the probability of the elderly falling into catastrophic health expenditures is higher than the other age group.

In Indonesia, there is a program called the Integrated Service Post (Posyandu). Other than Posyandu for children, there is Posyandu for the Elderly. This program aims to maintain and improve the health level of the elderly. Healthy elderly can reduce out-of-pocket health spending while avoiding catastrophic health expenditures. A study in Surabaya, Indonesia, stated that behavioral control is one aspect that affects the activity of the elderly in attending the Posyandu for the Elderly. Some of the components included in this aspect are ease of access, including distance, the energy needed, and time. ${ }^{20}$

This study found no difference in the probability of falling into catastrophic health expenditure between males and females. The result of this study does not in line with the previous study using data from 2012 in Indonesia that showed females have a positive relationship with catastrophic health expenditures. ${ }^{3}$ Meanwhile, ever-married people have a higher probability of 
falling into catastrophic health expenditure. This condition is more likely related to the relationship between marital status on health care utilization..$^{21,22}$

Similar to sex, the probability between population with highest level education completed is a primary school or lower and more than primary school also shows no difference. Meanwhile, for work status, people that are not working have a higher probability of falling into catastrophic health expenditure. A previous study confirmed that the head of a household that was not employed increased the likelihood of catastrophic health expenditure. ${ }^{10}$

Wealth is one of the factors that was significantly influencing higher out-of-pocket health expenditures. In this study, the probability of the population experiencing catastrophic health expenditure is higher in the group of highest $60 \%$ or not poor. This finding is in line with a study conducted in Indonesia in 2017 using the 2014 Susenas. It stated that out-of-pocket health expenditures increased along with improving economic status. ${ }^{23}$ The previous study in India also confirmed that the higher expenditure quintile is a significant predictor of high out-of-pocket health expenditures. ${ }^{24}$ This is likely related to the advantages possessed by the people with better levels of welfare or economic status. They have the option of obtaining healthcare. Although, they have to spend a large amount of money in return, increasing the risk of falling into catastrophic health expenditure.

Regarding variables related to territoriality, both types of area and geographic location are significantly associated with catastrophic health expenditure. People that live in rural areas, more likely to fall into catastrophic health expenditure. ${ }^{3,10}$ Meanwhile, people in Java Island have a higher probability of experiencing catastrophic health expenditure. One thing to note, we do not differentiate health expenditures by the healthcare facility. Thus, the results of this study do not imply that health costs in urban areas or on Java Island are more expensive than in rural areas or outside Java Island.

A previous study stated that zone association with catastrophic health expenditure could be due to variations regarding financing, delivery, or provision of health care services. ${ }^{6}$ The decentralization of the health sector implemented in Indonesia affects health services, especially in access to and management of the health system. Therefore, the central government, regional governments, the private sector, and the community need to cooperate to maximalized the benefit that came from the decentralization. ${ }^{25}$

\section{Conclusion}

One of the problems in achieving universal health coverage in Indonesia is catastrophic health expenditure. This study confirms the relationship between catastrophic health expenditure and its determinants, i.e., outpatient and service use, health insurance ownership, age, sex, marital status, educational level, work status, welfare status, the type of area, and geographic location. The 
probability of the population experiencing catastrophic health expenditure is higher for people who use inpatient or outpatient services. The probability is also higher for people in the following categories: do not have health insurance, are elderly, ever-married, not working, not poor, and live in the rural area or Java island. The disaggregation by outpatient and inpatient service use show a big difference in the probability of the population experiencing catastrophic health expenditure. Therefore, people need to maintain their health with low-cost to no-cost activities to avoid using outpatient or inpatient services. On the other hand, the government needs to promote healthy living, for example, by strengthening the PHBS or GERMAS Movement. In the future, we hope that studies on catastrophic health expenditure in Indonesia can be continued, for example, by using other statistical inferential tools. Thus, these studies can provide more comprehensive information about the phenomenon. Therefore, the government can also use it as input to achieve universal health coverage in Indonesia.

\section{Acknowledgement}

We want to thank BPS for providing data on the 2019 Susenas Module of Health and Housing. We also thank the Education and Training Centre of BPS (Pusdiklat BPS) for facilitating the workshop on research writing and the reviewers who have provided input on this study.

\section{Funding}

This study received no specific grant from any funding agency in the public, commercial, or not-for-profit sectors.

\section{Conflict of Interest}

The author declares that there is no conflict of interest.

\section{Reference}

1. Badan Pusat Statistik. Profil Kesehatan Ibu dan Anak 2020. Jakarta: Badan Pusat Statistik; 2020.

2. United Nation. SDG Indicators. In 2021 [accessed 2021 Jul 21]. p. 1095-1095. Available from: https://unstats.un.org/sdgs/metadata/?Text=\&Goal=3\&Target=3.8

3. Situmeang LE, Hidayat B. Pengaruh Kepemilikan Jaminan Kesehatan terhadap Belanja Kesehatan Katastropik Rumah Tangga di Indonesia Tahun 2012. J Kebijak Kesehat Indones JKKI [Internet]. 2018 Jul 19 [accessed 2021 Jul 21];7(1):1-9. Available from: https://journal.ugm.ac.id/jkki/article/view/12186

4. Wagstaff A, Flores G, Hsu J, Smitz MF, Chepynoga K, Buisman LR, van Wilgenburg K, 
Eozenou P. Progress on catastrophic health spending in 133 countries: a retrospective observational study. Lancet Glob Heal [Internet]. 2018 Feb 1 [accessed 2021 Jul 21];6(2):e169-79. Available from: http://www.thelancet.com/article/S2214109X17304291/ fulltext

5. Pandey A, Ploubidis GB, Clarke L, Dandona L. Trends in catastrophic health expenditure in india: 1993 to 2014. Bull World Health Organ [Internet]. 2018 Jan 1 [accessed $2021 \mathrm{Jul}$ 21];96(1):18-28. Available from: /pmc/articles/PMC5791868/

6. Aregbeshola BS, Khan SM. Determinants of catastrophic health expenditure in Nigeria. Eur J Heal Econ [Internet]. 2018 May 29 [accessed 2021 Jul 21];19(4):521-32. Available from: https://ink.springer.com/article/10.1007/s10198-017-0899-1

7. Kazemi-Galougahi MH, Dadgar E, Kavosi Z, Majdzadeh R. Increase of catastrophic health expenditure while it does not have socio-economic anymore; Finding from a district on Tehran after recent extensive health sector reform. BMC Health Serv Res [Internet]. 2019 Aug 14 [accessed 2021 Jul 21];19(1):1-12. Available from: https://bmchealthservres. biomedcentral.com/articles/10.1186/s12913-019-4418-1

8. Piroozi B, Moradi G, Nouri B, Bolbanabad AM, Safari H. Catastrophic health expenditure after the implementation of health sector evolution plan: A case study in the west of Iran. Int J Heal Policy Manag [Internet]. 2016 [accessed 2021 Jul 21];5(7):417-23. Available from: /pmc/articles/PMC4930347/

9. Myint CY, Pavlova M, Groot W. Catastrophic health care expenditure in Myanmar: Policy implications in leading progress towards universal health coverage. Int J Equity Health [Internet]. 2019 Jul 30 [accessed 2021 Jul 21];18(1):1-13. Available from: https://equityhealthj.biomedcentral.com/articles/10.1186/s12939-019-1018-y

10. Ghorbanian A, Rashidian A, Bagheri Lankarani K, Kavosi Z. The Prevalence and Determinants of Catastrophic Health Expenditures in Iran: A Systematic Review and MetaAnalysis. Heal Scope [Internet]. 2017 Oct 29 [accessed 2021 Aug 3];In Press(In Press). Available from: https://sites.kowsarpub.com/healthscope/articles/63210.html

11. Nugraheni WP, Hartono RK. Determinan Pengeluaran Kesehatan Katastropik Rumah Tangga Indonesia Pada Tahun Pertama Implementasi Program JKN. Bul Penelit Kesehat [Internet]. 2017 Mar 31 [accessed 2021 Jul 21];45(1):27-36. Available from: http://ejournal.litbang.kemkes.go.id/index.php/BPK/article/view/6069

12. Aji B, Mohammed S, Haque MA, Allegri M De. The Dynamics of Catastrophic and Impoverishing Health Spending in Indonesia: How Well Does the Indonesian Health Care Financing System Perform? Asia-Pacific J Public Heal [Internet]. 2017 Sep 1 [accessed 2021 Aug 10];29(6):506-15. Available from: https://pubmed.ncbi.nlm.nih.gov/28868904/

13. Badan Pusat Statistik. Buku 2 Manajemen Pelaksanaan Survei Sosial Ekonomi Nasional 
(Susenas) Modul Kesehatan dan Perumahan 2019. Jakarta: Badan Pusat Statistik; 2019.

14. Nihan ST. Karl Pearsons chi-square tests. Educ Res Rev [Internet]. 2020 [accessed 2021 Aug 3];15(9):575-80. Available from: http://www.academicjournals.org/ERR

15. Stata. Title stata.com estat gof-Pearson or Hosmer-Lemeshow goodness-of-fit test [Internet]. [accessed 2021 Oct 24]. Available from: https://www.statapress.com/data/r17/lbw

16. Okoroh J, Essoun S, Seddoh A, Harris H, Weissman JS, Dsane-Selby L, Riviello R. Evaluating the impact of the national health insurance scheme of Ghana on out of pocket expenditures: A systematic review. BMC Health Serv Res [Internet]. 2018 Jun 7 [accessed 2021 Aug 11];18(1):1-14. Available from: https://ink.springer.com/articles/10.1186/ s12913-018-3249-9

17. Mahumud RA, Sarker AR, Sultana M, Islam Z, Khan J, Morton A. Distribution and determinants of out-of-pocket healthcare expenditures in Bangladesh. J Prev Med Public Heal [Internet]. 2017 Mar 1 [accessed 2021 Aug 11];50(2):91-9. Available from: /pme/articles/PMC5398340/

18. Ghimire M, Ayer R, Kondo M. Cumulative incidence, distribution, and determinants of catastrophic health expenditure in Nepal: Results from the living standards survey [Internet]. Vol. 17, International Journal for Equity in Health. BioMed Central; 2018 [accessed 2021 Aug 17]. p. 1-12. Available from: https://equityhealthj.biomedcentral.com/articles/10.1186/ s12939-018-0736-x

19. Azzani M, Roslani AC, Su TT. Determinants of household catastrophic health expenditure: A systematic review. Malaysian J Med Sci [Internet]. 2019 [accessed 2021 Aug 17];26(1):15-43. Available from: /pmc/articles/PMC6419871/

20. Mindianata P. Faktor-Faktor Yang Berpengaruh Terhadap Niat Keaktifan Lansia dalam Mengikuti Posyandu Lansia. J Promkes Indones J Heal Promot Heal Educ [Internet]. 2018 Dec 12 [accessed 2021 Aug 17];6(2):213-26. Available from: https://www.ejournal.unair.ac.id/PROMKES/article/view/8155

21. Pandey KR, Yang F, Cagney KA, Smieliauskas F, Meltzer DO, Ruhnke GW. The impact of marital status on health care utilization among Medicare beneficiaries. Medicine (Baltimore) [Internet]. 2019 Mar 1 [accessed 2021 Oct 28];98(12):e14871. Available from: /pme/articles/PMC6709281/

22. Damiani G, Salvatori E, Silvestrini G, Ivanova I, Bojovic L, Iodice L, Ricciardi W. influence of socio-economic factors on hospital readmissions for heart failure and acute myocardial infarction in patients 65 years and older: Evidence from a systematic review [Internet]. Vol. 10, Clinical Interventions in Aging. Dove Press; 2015 [accessed 2021 Oct 
28]. p. 237-45. Available from:/pmc/articles/PMC4310718/

23. Tarigan I, Suryati T. Gambaran Out of Pocket pada Awal Era JKN di Indonesia. J Penelit dan Pengemb Pelayanan Kesehat [Internet]. 2018 Oct 9 [accessed 2021 Jul 21];141-6. Available from: http://ejournal2.litbang.kemkes.go.id/index.php/jpppk/article/view/536

24. Sinha R, Chatterjee K, Nair N, Tripathy P. Determinants of Out-of-Pocket and Catastrophic Health Expenditure: A Cross-sectional Study. Br J Med Med Res [Internet]. 2016 Jan 10 [accessed 2021 Aug 17];11(8):1-11. Available from: https://www.journaljammr.com/ index.php/JAMMR/article/view/10022

25. Rintani A, Wibowo A. Health Sector Decentralization and Its Implication To Health Services In Indonesia. J Ilmu Kesehat Masy [Internet]. 2019 Apr 8 [accessed 2021 Aug 17];10(1):1-14. Available from: https://ejournal.fkm.unsri.ac.id/index.php/jikm/article/view/318 